\title{
Differential effects of various types of disturbances on the structure of nematode assemblages: an experimental approach
}

\author{
Michaela Schratzberger ${ }^{1,2, *}$, Richard M. Warwick $^{1}$ \\ ${ }^{1}$ CCMS, Plymouth Marine Laboratory, Prospect Place, West Hoe, Plymouth PL1 3DH, United Kingdom \\ ${ }^{2}$ Institut für Hydrobiologie und Fischereiwissenschaft, Zeiseweg 9, D-22765 Hamburg, Germany
}

\begin{abstract}
The objective of this study was to test the hypotheses that (1) assemblages of the same broad group of animals respond in a differential way to different classes of disturbance (i.e. there is not simply a generalised stress response), and that (2) the nature of the response differs according to the environmental conditions that the assemblages normally experience. A series of microcosm experiments was carried out to evaluate the responses of intertidal nematode assemblages to treatments of physical and biological disturbance and organic enrichment. Assemblages from an exposed sandy estuary poor in organic matter and from a sheltered muddy estuary rich in organic matter were compared. Results from univariate, graphicaLdistributional and multivariate methods of data evaluation generally support our initial hypothesis that nematode assemblages exhibit various characteristic changes when exposed to different types of disturbances. Changes in assemblage structure were revealed depending on the type of disturbance, the initial structure of the assemblage and the morphological and physiological adaptations of the species. For both assemblages, biological disturbance caused the least severe changes in assemblage structure. For the sand nematodes, most extreme changes were the result of organic enrichment, while mud nematodes showed the most intense response to treatments of physical disturbance. Assemblages are most affected by the kinds of disturbances that they do not normally experience naturally.
\end{abstract}

KEY WORDS: Physical disturbance - Biological disturbance Organic enrichment - Microcosm experiments · Free-living nematodes - Estuaries - Diversity $\cdot$ Community structure

\section{INTRODUCTION}

One of the factors affecting species diversity is disturbance. The effects will depend on its type, frequency and intensity (Connell 1978, Huston 1979, 1996). Natural physical disturbances can take the form of currents and waves; biological disturbances may occur as predation or bioturbation. Anthropogenic impacts can appear in the form of organic enrichment resulting in an artificially high input of nutrients and organic matter in many coastal and offshore areas.

It has been suggested that responses of communities are non-specific to particular types of disturbances (Austen et al. 1994), although different types of distur-

•E-mail: msch@pml.ac.uk bances can cause responses on different levels of organisation (Hall 1994).

Field studies investigating the effects of different classes of disturbances on meiofauna have been conducted (e.g. Sherman et al. 1983, Hicks 1984, Alongi \& Christoffersen 1992). However, the results of such studies demonstrated that it is impossible to find field situations in which a certain type of disturbance can be investigated in isolation from all other parameters which affect community structure.

This problem can be overcome by the design of appropriate experiments in which environmental conditions and experimental variables can be controlled. Meiofaunal assemblages are ideal for experiments because of their short life-cycles and therefore their potential for rapid responses to environmental change (review by Coull \& Palmer 1984, Bell 1988, Bett 1988, 
Coull \& Giere 1988, Warwick et al. 1988, Moore \& Bett 1989, review by Coull \& Chandler 1992, Giere 1993, Warwick 1993).

A number of field and laboratory experiments have dealt with the effects of physical (Hall \& Harding 1997) and biological disturbance (Federle et al. 1983, Marinelli \& Coull 1987, Warwick et al. 1990, Olafsson \& Elmgren 1991, Henry \& Jenkins 1995, Gregg \& Fleeger 1997) and organic enrichment (Gee \& Warwick 1985, Sandulli \& De Nicola-Giudici 1989, Sundbäck et al. 1990, Webb 1996) on one type of assemblage. However, experiments on the effects of various types of disturbances on meiofauna assemblages from different environments in which different suites of species have evolved have not been undertaken

We studied nematode assemblages in laboratory microcosms, defined as having a volume $<1 \mathrm{~m}^{3}$ (UNESCO 1991). In a series of 5 sequential experiments natural nematode assemblages from sand and mud were exposed to physical and biological disturbance and to organic enrichment. Results from 3 of these experiments have already been used to evaluate the effects of varying intensity and frequency of these types of disturbances individually (Schratzberger \& Warwick 1998a,b, 1999j. In sand, species diversity was lowest in the sediments subjected to a high frequency of physical disturbance while in mud diversity was highest in the treatments with an intermediate frequency of disturbance (Schratzberger \& Warwick 1998a). Results from an organic enrichment study revealed that the same amount of organic matter administered in many small doses had a milder effect on community structure than when administered in fewer but larger doses (Schratzberger \& Warwick 1998b). Changes in nematode community structure due to crab feeding activity (biological disturbance) were the result of confounded effects of predation and modification of the sediment and were dependent on the frequency of disturbance events (Schratzberger \& Warwick 1999).

In this paper we present a meta-analysis of selected data from these microcosm experiments, plus 2 new data sets from experiments where treatments of continuous physical and biological disturbance were repeated. This has enabled us to compare the effects of the different types of disturbance, and specifically to test 2 null hypotheses:

(1) Communities of the same broad group of animals do not respond in a differential way to different classes of disturbance (i.e. there is simply a generalised stress response).

(2) The nature of the response does not differ according to the environmental conditions that the assemblage normally experiences

\section{MATERIAL AND METHODS}

Collection sites. Intertidal estuarine sediments with their natural meiofaunal communities were collected on 5 occasions between August 1995 and May 1997 from 2 sites in South West England at low tide. Sand was collected from Cockle Sands near the mouth of the Exe estuary at mean low water level. $10 \mathrm{~cm}$ diameter cores were used to a depth of $5 \mathrm{~cm}$ to transfer sand into a bucket. The sediment had a median particle diameter of $270 \mu \mathrm{m}$ (corresponding to the Wentworth grade 'Medium Sand'), with 0\% silt/clay $(<63 \mu \mathrm{m})$. At high tide the estuary is almost completely covered by water, but at low tide extensive sand-and mudflats are uncovered. The banks in the upper part of the estuary are muddy and become sandier near Exmouth. Conditions are fully marine at high tide in the lower part of the estuary. Salinity can drop to about $30 \mathrm{~S}$ at low tide (Holme 1949). The organic content of the sediment in this area is about $2 \%$ (A. Lindley pers. comm.).

Mud from mid-tide level near Antony at the Lynher estuary was scraped into a bucket from the top $0.5 \mathrm{~cm}$ using a spade. The sediment had a median particle diameter of $15 \mu \mathrm{m}$ (corresponding to Wentworth grade 'Silt'), with $98 \%$ silt/clay. The exposure time during spring tides varies between 5 and $6 \mathrm{~h}$. The salinity of the estuary in this region, measured at the time of low water springs, varies between $32 \mathrm{~S}$ in summer and $8 \mathrm{~S}$ in winter; interstitial salinities vary between 34 and $19 \mathrm{~S}$ respectively. The organic content of the sediment is about $13 \%$ (Warwick \& Price 1975).

Different sampling depths (top $5 \mathrm{~cm}$ for sand, top 0.5 $\mathrm{cm}$ for mud) were chosen to ensure that a large percentage of the nematodes at each site were included (Platt \& Warwick 1980).

On each sampling occasion the natural sediment stratification was recorded at both sites. Sand was aerated throughout the top $5 \mathrm{~cm}$. At the muddy site a thin $(-0.5 \mathrm{~cm})$ layer of brown, aerated sediment at the surface was overlying black, anoxic mud.

On return to the laboratory, sediment from each site was homogenised by gentle hand-stirring with a large spatula to reduce the initial variability between microcosms. $300 \mathrm{~g}$ of homogenised sand and $150 \mathrm{~g}$ of homogenised mud (4 replicates for each type) were fixed in $4 \%$ formalin in order to obtain samples of natural nematode assemblages from the field sampling sites.

Experimental set-up. Individual sand and mud microcosms consisted of $567 \mathrm{ml}$ glass bottles (diameter $7 \mathrm{~cm}$, height $18 \mathrm{~cm}$ ). Sand microcosms were filled with $300 \mathrm{~g}$ of homogenised Exe sand and topped up with filtered seawater of natural salinity ( $32 \mathrm{~S}$ ). Mud microcosms were filled with $150 \mathrm{~g}$ homogenised Lynher mud and topped up with filtered seawater of natural salinity 
(28 S). The microcosms (4 replicates for each treatment) were run as closed systems with aeration. Homogenisation of field collected sediment destroyed the natural stratification. All microcosms were left unmanipulated for up to $1 \mathrm{wk}$ until suspended sediment particles in the water column had settled. Sediment stratification, which was similar to that recorded at the sampling sites, had redeveloped.

Small enclosures like our microcosms are characterised by a larger surface area-to-volume ratio compared to natural sediment in the field. This can result in altered chemical and biological conditions in the water column due to surface growth of algae. Therefore, all experiments were run in the dark for 2 mo under constant environmental conditions at room temperatures of 18 to $20^{\circ} \mathrm{C}$.

Assessment of the microcosm effect. Enclosed nematode assemblages in microcosms are isolated from various influences to which assemblages at the field sampling sites are exposed. Laboratory conditions in our experiments differed from those in the natural environment in terms of light (constant darkness in microcosms), temperature (microcosm temperatures were kept constant and higher than field temperatures) and availability of food (no additional food in the control microcosms). In order to evaluate the realism and quality of the enclosed experimental units, nematode assemblages from the field sampling sites were compared to those which were maintained in undisturbed laboratory microcosms (controls) for 2 mo.

Experimental treatments. Sand and mud microcosms were exposed to 3 different kinds of disturbances simulating the effects of: (1) hydrodynamic reworking (physical disturbance); (2) excessive input of organic matter in the marine environment (organic enrichment) and; (3) biological reworking (biological disturbance) on nematode assemblages.

Control microcosms contained the same meiofaunal assemblages as the ones subjected to treatment but remained untreated throughout the experiments.

Physical disturbance (Expts 1 and 2): Physical disturbance was effected by leaving the microcosms on a shaker in constant speed so that the majority of sand and all the mud was in suspension for the duration of the experiments. Shallow-water meiofauna communities are continually exposed to bedload transport of sediment caused by wind-induced waves and tidal currents (Hogue 1982). The extent of exposure, however, is different at the field sampling sites. Due to the considerable width of the Exe estuary, fauna may be exposed to small wind-induced waves for most of the time as well as to Atlantic swell (Holme 1949), whereas the sheltered mudflats in the Lynher estuary are not subjected to severe physical disturbance even by strong gales (Warwick \& Price 1975).
Organic enrichment (Expt 3): Organic enrichment was effected by the addition of powdered Ascophyllum nodosum (L.) Le Jolis in total quantities equivalent to $100 \mathrm{~g} \mathrm{C} \mathrm{m}^{-2}$ (low treatment) or $200 \mathrm{~g} \mathrm{C} \mathrm{m}^{-2}$ (high treatment) to the microcosms. At the beginning of the experiment the powdered algae was sprinkled into the microcosms and left to settle onto the sediment surface. The A. nodosum contained $35 \%$ carbon and $1 \%$ nitrogen. The deposition of natural organic material (breakdown of macroalgae and terrestrial primary production etc.) in most inshore areas is estimated to be below $100 \mathrm{~g} \mathrm{C} \mathrm{m}^{-2} \mathrm{yr}^{-1}$, but human activity such as sewage sludge dumping can result in an excess of organic inputs into the marine environment (Gee \& Warwick 1985).

Biological disturbance (Expts 4 and 5): Biological disturbance was effected by leaving a single Carcinus maenas (L.) (carapace diameter $10 \mathrm{~mm}$ ) in the microcosms for the duration of the experiments. $C$. maenas (L.) was chosen because it has been shown to be one of the most common predators feeding on benthic invertebrates in the Exe and the Lynher estuaries (Gee 1987). The crab density in the microcosms corresponded to 1 ind. $0.004 \mathrm{~m}^{-2}$ (or 250 ind. $\mathrm{m}^{-2}$ ). Natural densities have been estimated up to 5 ind. $\mathrm{m}^{-2}$ (Munch-Petersen et al. 1982). It is unlikely that constant darkness in the experiments altered the activity patterns of $C$. maenas. The animals become active mainly at night and their locomotory rhythm has been shown to be of internal origin (Naylor 1960).

The levels of disturbances in the experiments were artificially high. However, high levels were necessary to optimise potential effects on sand and mud assemblages. Experiments investigating the effects of lower levels of physical disturbance (Alongi 1985), organic enrichment (Gee \& Warwick 1985) and biological disturbance (Raffaelli et al. 1989) showed that abnormally high levels of disturbance are often necessary in order to optimise disturbance effects. To underline the artificial character of the experimental treatments, treatments in Expts 1 and 2 will be referred to as 'shaker' treatments, in Expt 3 as the 'low algae' and 'high algae' treatments and in Expts 4 and 5 as 'crab' treatments (Table 1).

Sample processing. At the end of the experimental periods, sediments from each microcosm were fixed in $4 \%$ formalin and processed. After decanting the sand samples 5 times onto a $63 \mu \mathrm{m}$ sieve or after the initial washing of the mud samples onto a $63 \mu \mathrm{m}$ sieve, meiofauna was extracted with Ludox (McIntyre \& Warwick 1984, Somerfield \& Warwick 1996). The extraction was repeated 3 times for each sediment type.

Nematode abundances in both sediments were high and, therefore, subsamples were taken, applying an easy non-quantitative method described by Pfann- 
Table 1. Codes used to identify microcosms

\begin{tabular}{|c|c|c|}
\hline Treatment & Sand code & Mud code \\
\hline \multicolumn{3}{|l|}{ Expt 1} \\
\hline Undisturbed control & S-contr-1 & M-contr-1 \\
\hline Treatment on shaker & S-shaker-1 & M-shaker-1 \\
\hline \multicolumn{3}{|c|}{ Expt 2 (Schratzberger \& Warwick 1998a) } \\
\hline Undisturbed control & S-contr-2 & M-contr-2 \\
\hline Treatment on shaker & S-shaker-2 & M-shaker-2 \\
\hline \multicolumn{3}{|c|}{ Expt 3 (Schratzberger \& Warwick 1998b) } \\
\hline Undisturbed control & S-contr-3 & M-contr-3 \\
\hline $\begin{array}{l}\text { Addition of low amount } \\
\text { of powdered algae }\end{array}$ & S-low algae-3 & M-low algae-3 \\
\hline $\begin{array}{l}\text { Addition of high amount } \\
\text { of powdered algae }\end{array}$ & S-high algae-3 & M-high algae-3 \\
\hline \multicolumn{3}{|l|}{ Expt 4} \\
\hline Undisturbed control & S-contr- 4 & M-contr-4 \\
\hline Treatment with crab & S-crab-4 & $\mathrm{M}$-crab-4 \\
\hline \multicolumn{3}{|c|}{ Expt 5 (Schratzberger \& Warwick 1999) } \\
\hline Undisturbed control & S-contr-5 & M-contr-5 \\
\hline Treatment with crab & S-crab-5 & M-crab-5 \\
\hline
\end{tabular}

kuche \& Thiel (1988) and Somerfield \& Warwick (1996). The extract was placed into a beaker, made up to a standard volume with tap-water and stirred into suspension before subsamples were rapidly taken with a ladle. Subsamples, containing at least 200 specimens, were evaporated slowly in anhydrous glycerol and mounted evenly spread on slides for identification and counting.

Nematodes were identified to genus or species using the pictorial keys of Platt \& Warwick $(1983,1988)$ and Warwick et al. (1998).

Data processing. Total number of individuals, total number of species, Shannon-Weaver-Index $\left(H^{\prime}\right)$, species richness (Margalef's $d$ ) and evenness (Pielou's $J$ ) were calculated to describe nematode assemblage structure. In some cases transformation of the data did not result in homogeneity of variance. Therefore, Kruskal-Wallis 1 -way analysis by ranks was applied to test the null hypothesis $\left(\mathrm{H}_{0}\right)$ that the samples did not differ at $p<0.05$ followed by multiple comparisons tests (Conover 1980).

Diversity profiles were visualised by plotting $k$-dominance curves, in which species are ranked in decreasing order of dominance. The percentage cumulative abundance ( $k$-dominance) is then plotted against the species rank $k$ (Lambshead et al. 1983, Platt et al. 1984). A procedure described by Clarke (1990) was applied to test the null hypothesis $\left(\mathrm{H}_{0}\right)$ that the $k$-dominance curves were not significantly different from each other at $p<0.05$.
Non-parametric multi-dirnensional scaling (MDS) ordination using the Bray-Curtis similarity measure was applied to square-root transformed species abundance data followed by analysis of similarities (ANOSIM, Clarke 1993) to test the $H_{0}$ that there were no significant differences $(p<0.05)$ in nematode assemblage composition in different samples. These multivariate analyses constituted a meta-analysis of data from several experiments combined in a single MDS. In order to determine the contribution of individual species to the average Bray-Curtis dissimilarity between samples the 'similarity percentages' program SIMPER (Clarke \& Warwick 1994) was applied. All analyses were performed using the software package PRIMER, developed at the Plymouth Marine Laboratory (Clarke \& Warwick 1994).

\section{RESULTS}

\section{Effects of laboratory conditions on natural nematode assemblages}

The most consistent response of sand and mud nematodes to laboratory conditions was a decline of total nematode abundances in the control microcosms compared to the respective field samples (Table 2 ).

Nematode assemblages from the sand sampling site were dominated by Chromaspirina inglisi, Daptonema normandicum, Odontophora longisetosa and the Sabatieria species S. breviseta and S. pulchra. C. inglisi also dominated control microcosms together with Leptolaimus scotlandicus, Calomicrolaimus honestus and several Daptonema species.

Significant differences between nematode assemblages derived from the sand sampling site at the Exe estuary and assemblages from control microcosms were mainly due to decreasing abundances of the dominant species Chromaspirina inglisi and the predators Sigmophoranema litorale, Viscosia cobbi and $V$. viscosia. Despite their relatively low abundances in both field and control samples, nematode species

Table 2. Total nematode abundances (mean \pm SD) in the field samples and respective control microcosms. 'Significant difference at $p<0.05$

\begin{tabular}{|ccc|}
\hline Expt & $\begin{array}{c}\text { Sand } \\
\text { Field / control microcosm }\end{array}$ & $\begin{array}{c}\text { Mud } \\
\text { Field / control microcosm }\end{array}$ \\
\hline Expt 1 & $4145 \pm 1233 / 734 \pm 358^{\circ}$ & $16472 \pm 2968 / 2769 \pm 416^{\circ}$ \\
Expt 2 & $902 \pm 130 / 771 \pm 55^{\circ}$ & $44710 \pm 10810 / 16428 \pm 2756^{\circ}$ \\
Expt 3 & $2857 \pm 673 / 554 \pm 448^{\circ}$ & $27390 \pm 6147 / 12324 \pm 1675^{\circ}$ \\
Expt 4 & $3328 \pm 367 / 2024 \pm 1324$ & $11895 \pm 1182 / 5288 \pm 695^{\circ}$ \\
Expt 5 & $3822 \pm 794 / 2840 \pm 242^{\circ}$ & $10780 \pm 809 / 8115 \pm 1641^{\circ}$ \\
\hline
\end{tabular}


belonging to the family Chromadoridae proved to be good discriminators between natural assemblages and those maintained in microcosms under laboratory conditions. Abundances of Neochromadora trichophora, N. poecilosoma, Chromadora nudicapitata and Prochromadorella septempapillata were significantly higher in most field samples than in the respective controls.

Nematode assemblages collected at the mud sampling site showed high numbers of Ptycholaimellus ponticus, Metachromadora vivipara and the 2 Terschellingia species $T$. longicaudata and $T$. communis. All these species except for $P$. ponticus were also dominant in mud control microcosms.

The most common response of nematode assemblages collected at the mud sampling site to laboratory conditions was a significant decrease of the dominant species Ptycholaimellus ponticus and Metachromadora vivipara, whereas abundances of Terschellingia communis and $T$. longicaudata did not change significantly. Numbers of the low-abundance species Molgolaimus demani and Tripyloides sp. were significantly lower in most control microcosms compared to the respective field samples.

Developmental rate, fecundity and longevity are important factors in the life-history of organisms in determining the reproductive potential which is influenced by temperature, salinity and food availability. In the experiments, 2 of these factors (temperature and food availability) differed from those in the natural environment. Therefore, the reproductive potential of the nematodes may have been altered by the exposure to experimental conditions. However, nematodes of different developmental stages (juveniles, adult females and males of different sizes) were found in all control microcosms, indicating that reproduction and growth of most species occurred and appeared to have remained relatively unaffected by enclosure.

\section{Effects of various types of disturbances on nematode assemblages}

\section{Univariate indices}

As presented in Table 3 , sand and mud assemblages from the shaker and algae treatments were less diverse than those which remained unmanipulated. Changes in diversity due to crab disturbance were not significant at $\mathrm{p}<0.05$.
Dominance curves

$k$-dominance plots for nematode assemblages from the sand and mud microcosms are presented in Figs. 1 to 3. Unmanipulated sand assemblages were more diverse than those from the algae and shaker treatments. Assemblages from the crab treatments were more diverse than those which remained unmanipulated.

Mud nematode assemblages from the control microcosms were more diverse than those which were exposed to disturbance.

\section{Multivariate indices}

MDS plots representing the meta-analyses for the sand and mud microcosms are presented in Fig. 4. For both sand and mud nematodes, results of the pairwise analyses of similarities (ANOSIM) in Tables 4 \& 5 reveal that: (1) assemblages from all control microcosms were significantly different from each other, (2) assemblages from all treatments (except S-low algae-3/Shigh algae-3) were significantly different from each other, (3) assemblages from the control microcosms were significantly different from those from their respective treatments (except for S-contr-4/S-crab-4 and M-contr-5/M-crab-5) and (4) crab disturbance caused the least severe changes in nematode assemblage structure compared to other types of disturbance.

The information presented in the MDS plots (Fig. 4) together with results in Tables $4 \& 5$ reveals that sand and mud assemblages exposed to the same type of disturbance in replicated experiments were more similar to each other than to those exposed to any other type of disturbance.

Physically disturbed sand assemblages were more similar to biologically disturbed ones than to those which were exposed to organic enrichment and vice versa. For mud nematodes, however, the biologically disturbed and organically enriched assemblages were more similar to each other than to those which were disturbed physically and vice versa. 

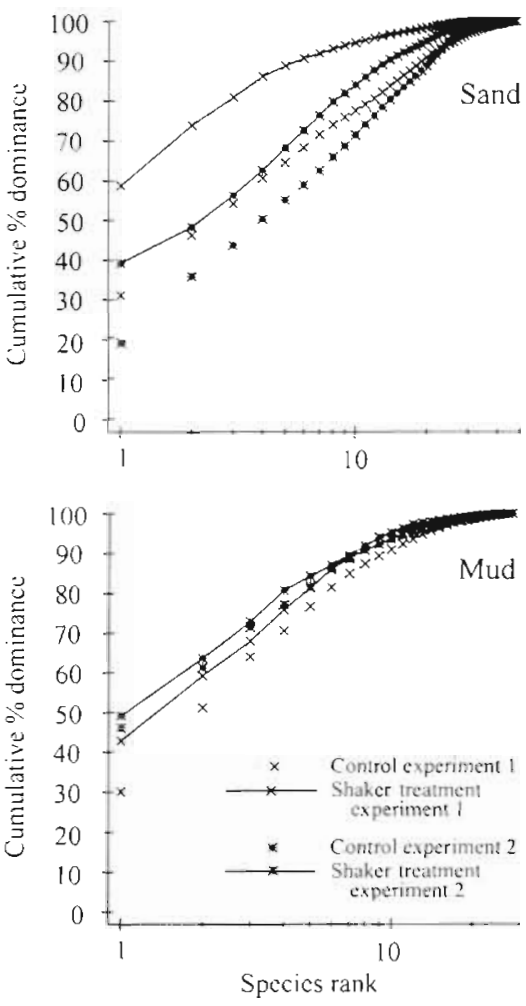

Fig. 1. K-dominance curves for sand and mud assemblages from controls and shaker treatments
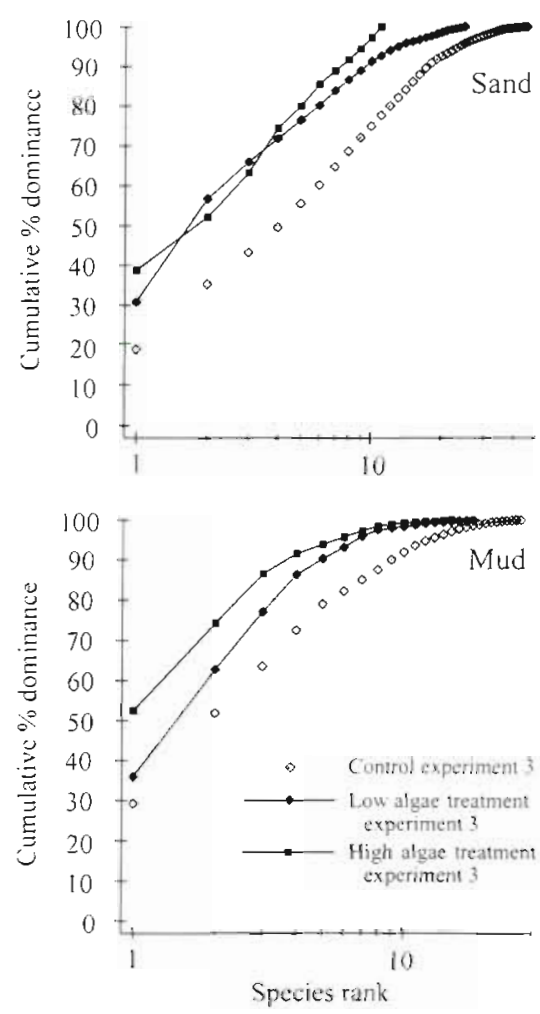

Fig. 2. K-dominance curves for sand and mud assemblages from controls and algae treatments
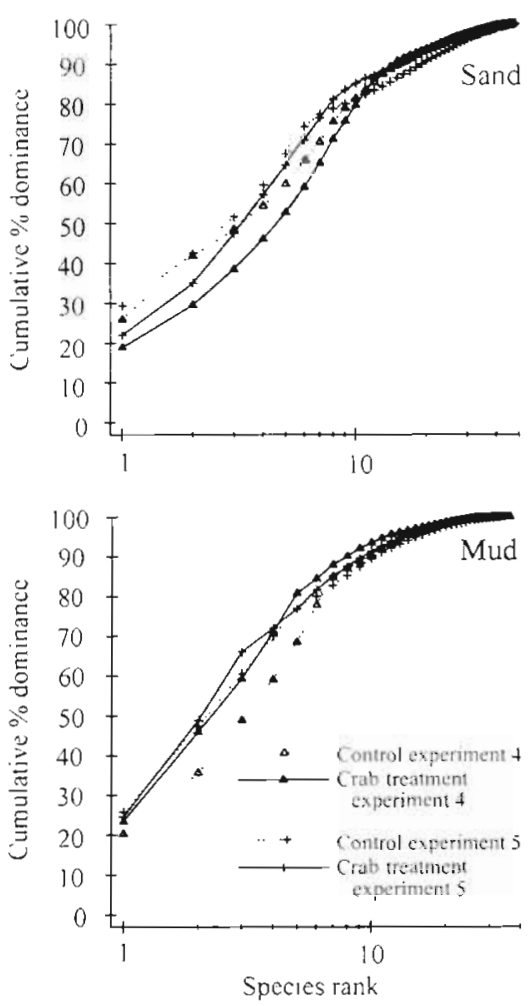

Fig. 3. K-dominance curves for sand and mud assemblages from controls and crab treatments

For the sand nematodes, the most severe changes in assemblage structure were detected in the algae treatments, whereas mud nematodes showed the most intense response to the experimental treatments of physical disturbance compared to other types of disturbances.

Sand assemblages from the shaker treatments were characterised by significantly higher abundances of Rhabditis marina (Expt 1) or significantly lower abundances of Camacolaimus barbatus (Expt 2) than those from algae or crab treatments. Daptonema normandicum was significantly less abundant in organically enriched sand assemblages than in those exposed to disturbance by Carcinus maenas.

A common response of mud nematodes to physical disturbance was a decline of Terschellingia longicaudata, whereas the response to organic enrichment was reflected in a decline of Molgolaimus demani compared to other types of disturbances.

\section{DISCUSSION}

\section{Effects of laboratory conditions on natural nematode assemblages}

The real world and the microcosm have their own distinct properties, which differ because of the effects 

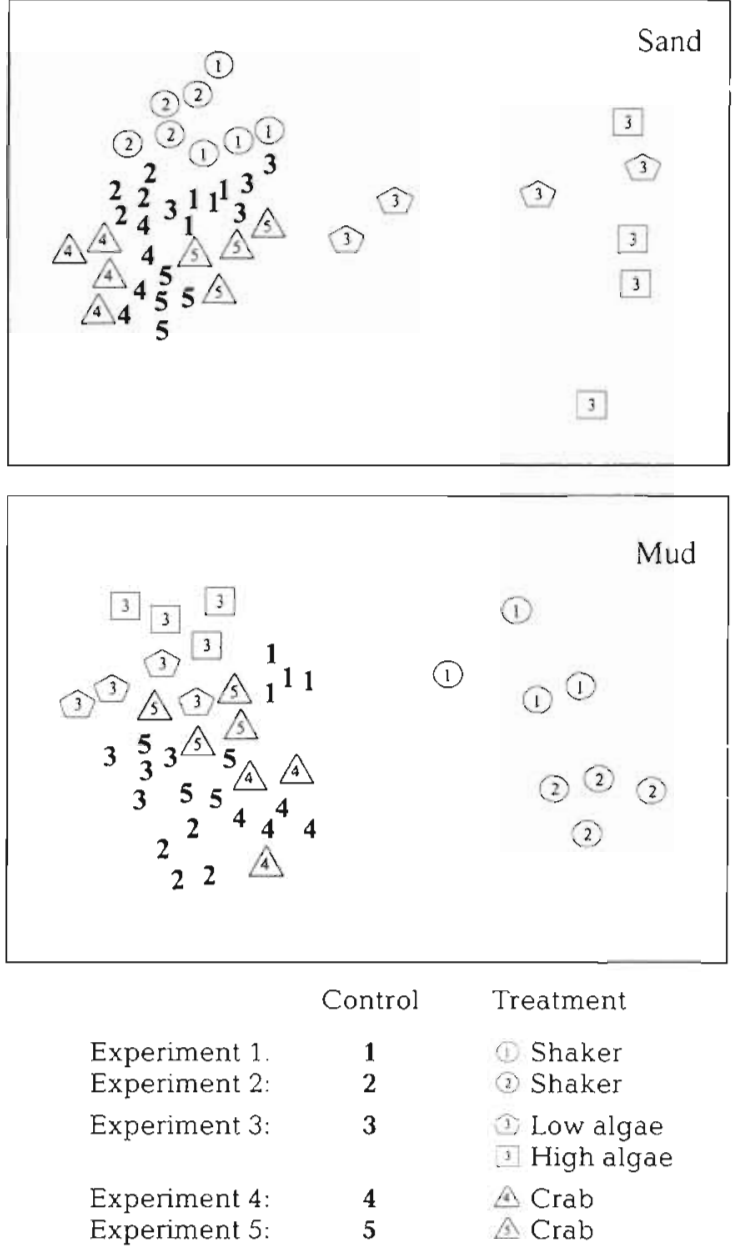

Fig. 4. MDS plots for nematode assemblages from the sand and mud microcosms. Stress value sand $=0.12$, stress value mud $=0.1$ of scaling, environmental heterogeneity, and species composition. Therefore, microcosms are valid models only for properties that are common both in nature and in the laboratory (Leffler 1980). Enclosure in microcosms and maintenance under laboratory conditions for an experimental period of $8 \mathrm{wk}$ resulted in the development of nematode assemblages which differed significantly from those living under natural conditions. In some respects these changes were similar regardless of whether nematode assemblages were derived from the sand or the mud sampling site. Most species survived in the control microcosms. Some species occurred in high numbers under experimental conditions while others, mainly chromadorids and some predatory species, did not. It is possible that the species which survived better in the microcosms are also those which are more resistant to disturbances in their natural environment (Austen et al. 1994). Changes in assemblage structure observed in the microcosm experiments were an integrated response to (1) the general experimental conditions ('microcosm effect') and (2) the experimental treatment. Total nematode abundances were higher in the controls than in the treatments so that the experimental treatment effect was sufficient to be detected over the microcosm effect in the short time period of the experiment.

\section{Effects of various types of disturbances on nematode assemblages}

Results showed that nematode assemblages from sand and mud exhibit different responses to various types of disturbances and, therefore, the first null hypothesis has to be rejected. Most methods of data evaluation revealed that for both sand and mud, crab disturbance had caused the least severe changes in the structure of the assemblages. For the sand nematodes, most extreme changes were detected in the algae treatments. Mud nematodes showed the most intense response to treatments of physical disturbance.

There was some ranking of susceptibility to disturbance based on species-specific properties such as morphological and physiological adaptations and population growth rates, which were reflected in the reproductive success. Some species in the treatments suffered more than others. Being less tolerant to distur- 
Table 5. Dissinilarities (\%) between nematode assemblages from the mud microcosms based on square-root transformed data. "Significant difference at $p<0.05$. Code as in Table 1. Bold: comparison between controls; box: comparison controlrespective treatment; italics: comparison between treatments

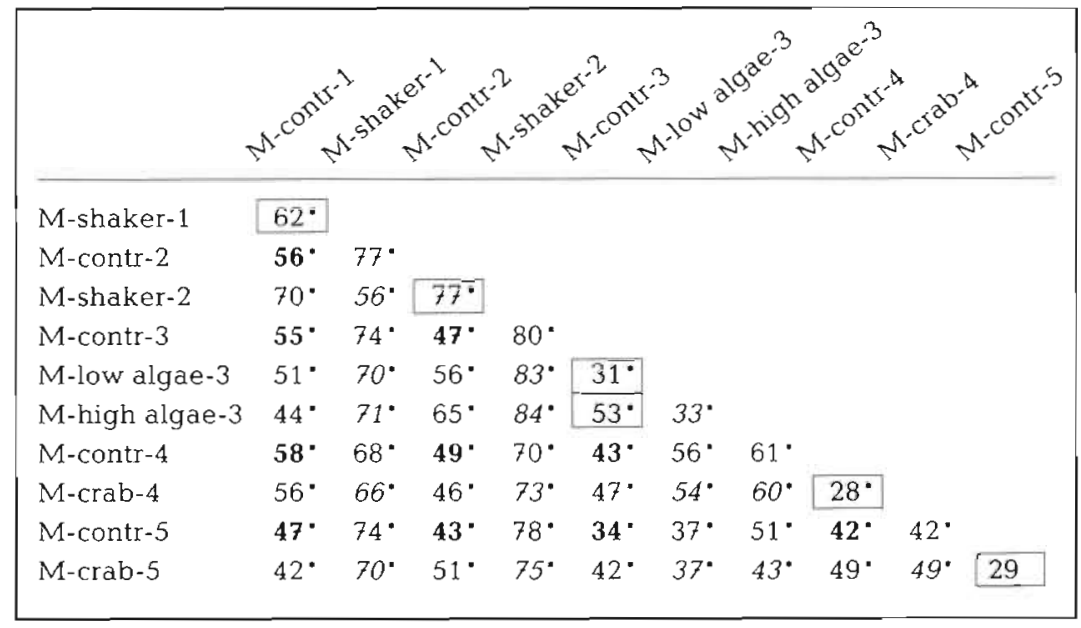

For both sediment types, physical disturbance in the first 2 experiments caused more severe changes in nematode assemblages than biological disturbance related to crab feeding activity in the Expts 4 and 5. Crabs had moulted during the 8 wk duration of the experiments indicating growth and good physiological condition. The crab treatment can be considered sufficient in affecting nematode assemblages in the sand and mud microcosms. Our results confirm those from Grant (1983), who compared tidal sediment reworking to biogenic reworking by benthicfeeding fishes and macrofaunal invertebrates (hemichordates, amphipods, polychaetes) on an intertidal sandflat in South Carolina (USA). He described much of the conspicuous

bance, they were more likely to die and thus their abundances decreased. Changes in abundances of more tolerant species were not detected because their reproduction and growth rates remained unaffected by the experimental treatments.

Although exposure to physical disturbance caused changes in both sand and mud assemblages, sand nematodes were less affected than those from mud. Changes in the sediment environment were caused by high turbulence and shifting sediments. In contrast to most dominant species in the mud controls, those in unmanipulated sand display adaptations such as long cephalic setae which have been considered to provide an anchorage for nematodes in highly dynamic environments (Warwick 1971, Platt 1977).

Terschellingia longicaudata dominated nematode assemblages from the mud sampling site and control microcosms but abundances decreased significantly in the shaker treatments. $T$. longicaudata is a slowmoving bacterial feeder, with slow reproduction and population growth rates (Warwick \& Price 1979). Declining abundances indicate that these nematodes were not able to complete the life-cycles successfully and grow sufficiently and rapidly.

The addition of powdered algae to the microcosms decreased the availability of oxygen as evident from the smell of $\mathrm{H}_{2} \mathrm{~S}$ in the treatments. Sand assemblages from the algae treatments changed more dramatically than the respective mud assemblages. Mud nematodes are adapted to oxygen-poor sediment as reflected in the dominance of species with extremely low respiration rates in the unmanipulated sediments, e.g. Metachromadora vivipara and Terschellingia spp. (Warwick \& Price 1979). bioturbation by large animals as 'noise' compared to the structure imposed by the physical environment (tidal reworking).

These results demonstrated that the effects of various types of disturbances depend on the structure of the receiving assemblage and on morphological and physiological adaptations of the species to natural conditions. Therefore, the second null hypothesis has to be rejected.

Results from field studies have suggested that meiofaunal assemblages in sandy and muddy environments are controlled by 2 different mechanisms. Hydrodynamic activity was proposed as a mechanism determining the assemblage structure at unstable, tidal beaches, whereas biological interactions such as competition and predation were thought to be the mechanism controlling the seasonal abundance patterns at more stable atidal beaches (Hulings \& Gray 1976, Eskin \& Coull 1987). Our results support these assumptions, but never before have they been tested in experimental studies.

The results presented here contribute to a better understanding of benthic processes and improved the precision with which the response of the biota to environmental change can be determined. The experimental approach proved to be a powerful tool for the evaluation of environmental impacts. The forging of closer Links between laboratory and field-based research remains a fundamentally important goal of future studies on the impact of disturbances on marine assemblages and communities.

Acknowledgements. We thank members of the Plymouth Marine Laboratory's marine biodiversity group for practical 
assistance, and especially David Pearce, Melanie Austen, Andrea McEvoy, Paul Somerfield, Nicoletta Villano and Sergio Netto for field sampling assistance and for assistance in maintaining the experiments. We are grateful to the crew of the PML research vessel 'Sepia' for help with the collection of the crabs and to Bob Clarke, Martin Carr and Paul Somerfield for advice on the statistical analyses. The work was supported by an European Community MAST programme training grant to M.S., Contract no. MAS3-CT96-5041. This article is based on a doctoral study by M.S. in the Faculty of Biology, University of Hamburg. R.M.W.'s contribution was partly funded by the Ministry of Agriculture, Fisheries and Food (Contract no. AE 1113)

\section{LITERATURE CITED}

Alongi DM (1985) Effects of physical disturbance on population dynamics and trophic interactions among microbes and meiofauna. J Mar Res 43:351-364

Alongi DM, Christoffersen P (1992) Benthic infauna and organism-sediment relations in a shallow, tropical coastal area: influence of outwelled mangrove detritus and physical disturbance. Mar Ecol Prog Ser 81:229-245

Austen MC, McEvoy A, Warwick RM (1994) The specificity of meiobenthic community responses to different pollutants: results of microcosm experiments. Mar Pollut Bull 28 $557-563$

Bell SS (1988) Experimental techniques. In: Higgins RP, Thiel $\mathrm{H}$ (eds) Introduction to the study of meiofauna. Smithsonian Institution Press, Washington, p 169-180

Bett B (1988) Monitoring with meiofauna. Mar Pollut Bull 19 293-295

Clarke KR (1990) Comparisons of dominance curves. J Exp Mar Biol Ecol 138:143-157

Clarke KR (1993) Non-parametric multivariate analyses of changes in community structure. Aust $\mathrm{J}$ Ecol 18: $117-143$

Clarke KR, Warwick RM (1994) Change in marine communities: an approach to statistical analysis and interpretation. Plymouth Marine Laboratory, Plymouth

Connell JH (1978) Diversity in tropical rain forests and coral reefs. Science 199:1302-1310

Conover WJ (1980) Practical non-parametric statistics. John Wiley \& Son, New York

Coull BC, Chandler GT (1992) Pollution and meiofauna: field, laboratory and mesocosm studies. Oceanogr Mar Biol Annu Rev 30:191-271

Coull BC, Giere O (1988) The history of meiofaunal research. In: Higgins RP, Thiel $\mathrm{H}$ (eds) Introduction to the study of meiofauna. Smithsonian Institution Press, Washington, p $14-17$

Coull BC, Palmer MA (1984) Field experimentation in meiofaunal ecology. Hydrobiologia 118:1-19

Eskin RA, Coull BC (1987) Seasonal and three-year variability of meiobenthic nematode populations at two estuarine sites. Mar Ecol Prog Ser 41:295-303

Federle TW, Livingston RJ, Meeter DA, White DC (1983) Modifications of estuarine sedimentary microbiota by exclusion of epibenthic predators. J Exp Mar Biol Ecol 73:81-94

Gee JM (1987) Impact of epibenthic predation on estuarine intertidal harpacticoid copepod populations. Mar Biol 96 $497-510$

Gee JM, Warwick RM (1985) Effects of organic enrichment on meiofaunal abundance and community structure in sublittoral soft sediments. J Exp Mar Biol Ecol 91:247-262
Giere O (1993) Meiobenthology-the microscopic fauna in aquatic sediments. Springer-Verlag, Berlin

Grant J (1983) The relative magnitude of biological and physical sediment reworking in an intertidal community J Mar Res 41:673-689

Gregg JC, Fleeger JW (1997) Importance of emerged and suspended meiofauna to the diet of the darter goby (Gobionellus bolesoma Jordan and Gilbert). J Exp Mar Biol Ecol 209:123-142

Hall SJ (1994) Physical disturbance and marine benthic communities: life in unconsolidated sediments. Oceanogr Mar Biol Annu Rev 32:179-239

Hall SJ, Harding MJC (1997) Physical disturbance and marine benthic communities: the effects of mechanical harvesting of cockles on non-target benthic infauna. J Appl Ecol 34:497-517

Henry BA, Jenkins GP (1995) The impact of predation by the gridled goby, Nesogobius sp. 1 on abundances of meiofauna and small macrofauna. J Exp Mar Biol Ecol 191:223-238

Hicks GRF (1984) Spatio-temporal dynamics of meiobenthic copepod and the impact of predation-disturbance. J Exp Mar Biol Ecol 81:47-72

Hogue EW (1982) Sediment disturbance and spatial distributions of shallow water meiobenthic nematodes on the open Oregon coast. J Mar Res 40:551-573

Holme NA (1949) The fauna of sand and mud banks near the mouth of the Exe Estuary. J Mar Biol Assoc UK 28:189-237

Hulings NC, Gray JS (1976) Physical factors controlling abundance of meiofauna on tidal and atidal beaches. Mar Biol $34: 77-83$

Huston MA (1979) A general hypothesis of species diversity. Am Nat 113:81-101

Huston MA (1996) Biological diversity. Cambridge University Press, Cambridge

Lambshead PJD, Platt HM, Shaw KM (1983) The detection of differences among assemblages of marine benthic species based on an assessment of dominance and diversity. J Nat Hist 17:859-874

Leffler JW (1980) Microcosmology: theoretical applications of biological models. In: Giesy JP (ed) Microcosms in ecological research. Technical Information Centre, US Department of Energy, Springfield, VA, p 14-29

Marinelli RL, Coull BC (1987) Structural complexity and juvenile fish predation on meiobenthos: an experimental approach. J Exp Mar Biol Ecol 108:67-81

McIntyre AD, Warwick RM (1984) Meiofauna techniques. In: Holme NA, McIntyre AD (eds) Methods for the study of marine benthos. IBH Handbook No. 16, 2nd edn. Blackwell, Oxford, p 217-244

Moore CG, Bett BJ (1989) The use of meiofauna in marine pollution impact assessment. Zool J Linn Soc 96:263-280

Munch-Petersen S, Sparre P, Hoffmann E (1982) Abundance of the shore crab, Carcinus maenas (L.), estimated from mark-recapture experiments. Dana 2:97-121

Naylor E (1960) Locomotory rhytms in Carcinus maenas (L.) from non-tidal conditions. J Exp Biol 37:481-488

Olafsson E, Elmgren R (1991) Effects of biological disturbance by benthic amphipods Monoporeira affinis on meiobenthic community structure: a laboratory approach. Mar Ecol Prog Ser 74:99-107

Pfannkuche O, Thiel H (1988) Sample processing. In: Higgins $\mathrm{RP}$, Thiel $\mathrm{H}$ (eds) Introduction to the study of meiofauna. Smithsonian Institution Press, Washington, p 134-145

Platt HM (1977) Vertical and horizontal distribution of freeliving marine nematodes from Strangford Lough, Northern Ireland. Cah Biol Mar 18:261-273

Platt HM, Warwick RM (1980) The significance of free-living 
nematodes to the littoral ecosystem. In: Price JH, Irvine DEG, Farnham WF (eds) The shore environment, Vol 2, Ecosystems. Academic Press, London, p 729-759

Platt HM, Warwick RM (1983) Free-living marine nematodes Part I. British enoploids. Cambridge University Press Cambridge

Platt HM, Warwick RM (1988) Free-living marine nematodes. Part II. British chromadorids. Cambridge University Press, Cambridge

Platt HM, Shaw KM, Lambshead PJD (1984) Nematode species abundance patterns and their use in the direction of environmental perturbations. Hydrobiologia 118: $59-66$

Raffaelli D, Conacher A, McLachlan H, Emes C (1989) The role of epibenthic crustacean predators in an estuarine food web. Estuar Coast Shelf Sci 28:149-160

Sandulli R, De Nicola-Giudici M (1989) Effects of organic enrichment on meiofauna: a laboratory study. Mar Pollut Bull 20:223-227

Schratzberger M, Warwick RM (1998a) Effects of physical disturbance on nematode assemblages in sand and mud: a microcosm experiment. Mar Biol 130:643-650

Schratzberger M, Warwick RM (1998b) Effects of the intensity and frequency of organic enrichment on two estuarine nematode communities. Mar Ecol Prog Ser 164:83-94

Schratzberger M, Warwick RM (1999) Impact of predation and sediment disturbance by Carcinus maenas (L.) on free-living nematode community structure. J Exp Mar Biol Ecol 235:255-271

Sherman KM, Reidenauer JA, Thistle D, Meeter D (1983) Role of a natural disturbance in an assemblage of marine freeliving nematodes. Mar Ecol Prog Ser 11:23-30

Somerfield PJ, Warwick RM (1996) Meiofauna in marine pol-

Editorial responsibility: Otto Kinne (Editor),

Oldendorf/Luhe, Germany lution monitoring programmes. A laboratory manual. Ministery of Agriculture, Fisheries and Food, Directorate of Fisheries Research, Lowestoft

Sundbäck K, Jönnson B, Nilsson P, Lindström I (1990) Impact of accumulating drifting macroalgae on a shallow-water sediment system: an experimental study. Mar Ecol Prog Ser 58:261-274

UNESCO (1991) Manual on marine experimental ecosystems. UNESCO Tech Pap Mar Sci 61:1-178

Warwick RM (1971) Nematode associations in the Exe Estuary. J Mar Biol Assoc UK 51:439-454

Warwick RM (1993) Environmental impact studies on marine communities: pragmatical considerations. Aust J Ecol 18: $63-80$

Warwick RM, Price R (1975) Macrofauna production in an estuarine mud-flat. J Mar Biol Assoc UK 55:1-18

Warwick RM, Price R (1979) Ecological and metabolic studies on free-living nematodes from an estuarine mud-flat. Estuar Coast Mar Sci 9:257-271

Warwick RM, Carr MR, Clarke KR, Gee JM, Green RH (1988) A mesocosm experiment on the effects of hydrocarbon and copper pollution on a sublittoral soft-sediment meiobenthic community. Mar Ecol Prog Ser 46:181-191

Warwick RM, Clarke KR, Gee JM (1990) The effect of disturbance by soldier crabs Mictyris platycheles $\mathrm{H}$. Milne Edwards on meiobenthic community structure. J Exp Mar Biol Ecol 135:19-33

Warwick RM, Platt HM, Somerfield PJ (1998) Free-living marine nematodes. Part III. British monohysterids. Field Studies Council, Shrewsbury

Webb DG (1996) Response of macro- and meiobenthos from a carbon-poor sand to phytodetrital sedimentation. J Exp Mar Biol Ecol 203:259-271

Submitted: August 24, 1998; Accepted: January 25, 1999 Proofs received from author(s): May 4, 1999 